\title{
ANALISIS DAMPAK PENERAPAN GOOGLE CLASSROOM DALAM PEMBELAJARAN DARING SEMASA PANDEMI
}

\author{
Oleh : \\ Katmiasih", Muhammad Syahril Harahap $^{2}$, Sinar Depi Harahap ${ }^{3}$ \\ Fakultas MIPA Program Studi Pendidikan Matematika \\ Institut Pendidikan Tapanuli Selatan
}

\begin{abstract}
The aim of this research is to know the impact of applying google classroom toward teachers and students SMK Negeri 1 Marancar online learning in pandemic period. The approach of the research used qualitative descriptive and triangulation was applied on data analysis technique which included interview, documentation, and questionnaire. Data sources were 2 teachers and 10 students. The result of the research shows the impact of online learning is positive impact which includes increase students and teachers ability of using ICT, shorter study time, learning can be done anywhere, and availability of adequate file storage space, and minimize of using paper. Furthermore, negative impact includes difficult to apply the right learning methods and media, learning materials are only in the form of documents, network interference, additional costs for buying internet quota, unfavorable class atmosphere, students become lazy to study, low student manners, teachers and students have to have adequate smartphone.
\end{abstract}

\section{Keywords: The Impact Of Applying Google Classroom, Online Learning, Pandemic}

Penelitian ini bertujuan untuk mengetahui dampak penerapan google classroom terhadap pembelajaran daring guru dan siswa SMK Negeri 1 Marancar pada masa pandemi. Pendekatan penelitian ini menggunakan deskriptif kualitatif dan triangulasi diterapkan pada teknik analisis data yang meliputi wawancara, dokumentasi, dan angket. Sumber data adalah 2 guru dan 10 siswa. Hasil penelitian menunjukkan dampak pembelajaran daring adalah dampak positif yang meliputi peningkatan kemampuan siswa dan guru dalam menggunakan TIK, waktu belajar yang lebih singkat, pembelajaran dapat dilakukan di mana saja, dan ketersediaan ruang penyimpanan file yang memadai, dan meminimalkan penggunaan kertas. Selanjutnya dampak negatifnya antara lain sulitnya menerapkan metode dan media pembelajaran yang tepat, materi pembelajaran hanya berupa dokumen, gangguan jaringan, tambahan biaya untuk membeli kuota internet, suasana kelas yang kurang kondusif, siswa menjadi malas belajar, sopan santun siswa rendah, guru dan siswa harus memiliki smartphone yang memadai.

\section{Keywords: Dampak Penerapan Google Classroom, Pembelajaran Daring, Pandemi}

\section{PENDAHULUAN}

Pendidikan adalah suatu pondasi dalam hidup yang harus dibangun dengan sebaik mungkin. Pendidikan memegang peranan penting dalam pembangunan bangsa, suatu negara dikatakan berkembang apabila pendidikannya berkembang dan berkualitas. Berdasarkan UU No. 20 tahun 2003 pendidikan adalah usaha sadar dan terencana untuk mewujudkan suasana belajar dan proses pembelajaran agar peserta didik secara aktif mengembangkan potensi dirinya untuk memiliki kekuatan spiritual keagamaan, pengendalian diri, kepribadian, kecerdasan, akhlak mulia, serta keterampilan yang diperlukan dirinya, masyarakat, bangsa dan negara.

Pendidikan terdiri atas berbagai rumpun ilmu, salah satunya adalah pendidikan matematika. Matematika disamping dapat berkembang secara mandiri, juga berkembang atas tuntunan keperluan bidang-bidang lain. Proses pembelajaran yang berlangsung baik tingkat Sekolah Dasar, Menengah maupun Perguruan Tinggi memiliki 2 faktoryaitu, faktor internal dan faktor eksternal. Faktor internal siswa yang dapat mempengaruhi pembelajaran adalah minat belajar siswa. Adapun faktor eksternal yang mempengaruhi pembelajaran adalah lingkungan yang kurang mendukung dalam proses pembelajaran serta penggunaan teknologi yang diterapkan.

*(Penulis Korespondensi 
Penggunaan teknologi yang berkaitan dengan media pembelajaran dapat berperan banyak untuk meningkatkan minat belajar siswa dan untuk dapat menggunakan teknologi terbaru dalam proses pembelajaran dengan sebaik mungkin. Penggunaan teknologi ini memiliki peran besar dalam lembaga pendidikan, termasuk di dalamnya adalah pencapaian tujuan pembelajaran jarak jauh Korucu dan Alkan (dalam Firman, 2020). Berbgai media juga dapat digunakan untuk mendukung pelaksanaan pembelajaran secara daring. Misalnya menggunakan layanan google classroom, edmodo, google meet dan zoom, serta aplikasi pesan instan seperti whatsapp, email, dan telegram. Adapun aplikasi berbasis teknologi yang melakukan proses pembelajaran daring dan bisa dimanfaatkan dalam proses pembelajaran salah satunya yaitu google classroom.

Pemanfaatan google classroom dalam proses pembelajaran memungkinkan terciptanya ruang kelas di dunia maya. Selain itu, geogle classroom bisa menjadi sarana distribusi tugas, submit tugas bahkan menilai tugas-tugas yang dikumpulkan Herman (dalam Nirfayanti and Nurbaeti, 2019). Dengan google classroom guru dapat dengan efektif dan efisien dalam pengelolaan kelas Azhar dan Iqbal (dalam Elfauziah, dkk, 2019). Dengan demikian, aplikasi ini dapat membantu memudahkan Guru dan Siswa dalam melaksanakan proses belajar dengan lebih mendalam dimasa pandemi covid-19 saat ini. Hal ini disebabkan karena baik guru maupun Siswa dapat mengumpulkan tugas, mendistribusikan tugas, menilai tugas dirumah ataupun dimanapun tanpa terikat batas waktu atau jam pelajaran.

Pada tanggal 31 desember 2019 di Wuhan, China ada suatu penyakit yang disebabkan oleh virus yang bernama corona atau dikenal dengan istilah covid-19 (corona virus diseases-19) yang menyerang pernapasan manusia. Virus ini diduga muncul karena adanya pasar makanan yang menjual berbagai jenis hewan hidup maupun sudah mati Pratiwi (dalam Simatupang, 2020:1), dimana pasar tersebut memperjualbelikan hewan, termasuk hewan liar diantaranya seperti rubah, buaya, anak anjing, serigala, ular, tikus, landak, kelelawar,buruk merak bahkan koala, hewanhewan tersebut dijual dalam keadaan hidup maupun mati. Penularan covid-19 sangat cepat menyebar ke berbagai negara di dunia, sehingga organisasi kesehatan dunia atau WHO (Whorld Health Organization) menyatakan wabah penyebaran covid-19 sebagai pandemi dunia saat ini.

Penyebaran covid-19 ini memiliki beberapa dampak di antaranya yaitu tidak hanya mempengaruhi sistem ekonomi di Indonesia, akan tetapi berpengaruh secara global di semua sektor kehidupan manusia. Hal ini juga berdampak pada sistem pendidikan di indonesia. Berdasarkan Kemendikbud 2020, menteri pendidikan mengeluarkan Surat Edaran Nomor 3 Tahun 2020 tentang pencegahan corona virus disiase (covid-19) pada satuan pendidikan yang menyatakan bahwa meliburkan sekolah dan perguruan tinggi. Dengan meliburkan sekolah dan perguruan tinggi menteri pendidikan juga mengganti proses kegiatan belajar mengajar (KBM) dengan menggunakan sistem pembelajaran daring. Melihat situasi di masa pandemi covid-19 bahwa proses pembelajaran tidak berjalan secara efektif, dimana pembelajaran yang dilakukan secara daring sulit dilaksanakan diberbagai daerah.

Sehingga pembelajaran pada masa pandemi saat ini, lebih diarahkan pada pembelajaran daring dengan bantuan teknologi canggih dengan harapan dapat membantu siswa mencerna materi pembelajaran secara interaktif, produktif, efektif, inspiratif, kontruktif dan menyenangkan. Pembelajaran online (online learning) merupakan pembelajaran yang dapat memfasilitasi pembelajaran menjadi lebih luas, lebih banyak dan bervariasi. Guru dan siswa juga bisa berkomunikasi secara interaktif melalui pembelajaran tersebut yang difasilitasi dengan komputer, internet, atau smartphone. Dengan adanya era teknologi yang semakin berkembang maka program pembelajaran diarahkan untuk bisa memanfaatkan teknologi dengan lebih baik. Kegiatan pembelajaran menggunakan Media e-learning disekolah tersebut memanfaatkan aplikasi Geogle Classroom. Namun seiring dengan penerapan pembelajaran menggunakan aplikasi google classroom pembelajaran yang semestinya berjalan dengan baik dan sesuai dengan mutu pendidikan yang berlaku serta diharapkan agar proses pembelajaran tetap dapat berjalan sebagaimana mestinya. Berdasarkan wawancara yang dilakukan peneliti pada tanggal 05 Maret 2021 guru mata pelajaran matematika menyatakan mulai pada saat google classroom diterapkan sebagai media pembelajaran daring terdapat banyak dampak di antaranya yaitu membuat siswa malas belajar dari 24 siswa hanya sekitar 17 siswa yang aktif. Dimana siswa hanya sering aktif dalam mengabsen saja,siswa sering tidak mengerjakan tugas yang diberikan oleh guru hal tersebut disebabkan karna guru memberikan materi pembelajaran berupa dokumen dan video penjelasan singkat yang membuat siswa kurang memahaminya. Alasan lainnya yaitu jika mereka tidak mengerjakan tugas selama pembelajaran menggunakan google classroom pada pembelajaran 
daring ini maka mereka tidak akan mendapatkaan hukuman seperti yang terjadi pada saat pembelajaran tatap muka (Sri Rohana Harianja, 05 Maret 2021).

\section{METODE PENELITIAN}

Metode penelitian yang digunakan peneliti adalah metode penelitian kualitatif. Sebuah penelitian kualitatif terdapat objek penelitian dan informan penelitian. Adapun yang menjadi objek penelitian ini adalah apa saja saja gambaran dampak penerapan google classroom dalam pembelajaran daring semasa pandemi. Serta informan penelitian ini adalah guru dan siswa di SMK Negeri 1 Marancar. Sumber data primer penelitian ini adalah guru mata pelajaran matematika dan siswa SMK Neferi 1 Marancar melalui wawancara dan angket. Sumber data sekunder dalam penelitian ini adalah buku-buku pendidikan maupun jurnal pendidikaan.

Teknik pengumpulan data penelitian ini dengan menggunakan wawancara, angket dan dokumentasi. Wawancara yang digunakan adalah wawancara semiterstruktur (semistructure interview) dan angket yang digunakan adalah angket tertutup. Adapun teknik dan instrumen pengumpulan data pada tabel berikut:

Tabel. 1 Teknik dan instrumen pengumpulan data

\begin{tabular}{cll}
\hline No & \multicolumn{1}{c}{ Teknik } & \multicolumn{1}{c}{ Jenis instrument } \\
\hline 1 & Wawancara & Kisi-kisi wawancara, lembar wawancara. \\
\hline 2 & Angket & Kisi-kisi angket, lembar angket, lembar penilaian angket. \\
\hline 3 & Dokumentasi & Kisi-kisi dokumen, lembar dokumentasi. \\
\hline
\end{tabular}

Berdasarkan uraian di atas maka peneliti menggunakan skala likertdalam penelitian ini, yaitu dengan jawaban dengan perhitungan Selalu $=4$, Sering= 3, Kadang-kadang= 2, Tidak Pernah= 1 . Instrumen penelitian yang menggunakan skala likert dapat dibuat dalam bentuk cheklis pada instrumen angket dampak penerapan google classroom semasa pandemi terhadap guru dan siswa. Pada angket dampak penerapan google classroom semasa pandemi terhadap guru dan siswa berisi 25 pertanyaan yang terdiri dari empat pilihan jawaban.

Tabel. 2 Penskoran Hasil Angket Skala Likert

\begin{tabular}{|c|c|c|}
\hline Skor & Alternatif Jawaban & Nomor Item \\
\hline 4 & Selalu (S) & \multirow{4}{*}{$\begin{array}{c}1,2,3,4,5,6,7,8,9,10,11 \\
12,13,14,15,16,17,18,19,20,21 \\
, 22,23,24,25\end{array}$} \\
\hline 3 & Sering $(S)$ & \\
\hline 2 & Kadang-Kadang (KK) & \\
\hline 1 & Tidak Pernah (TP) & \\
\hline
\end{tabular}

Arikunto ( dalam Rambe,2020:32)

Hasil angket mengenai dampak penerapan google classroom terhadap guru dan siswa dapat dihitung dengan menggunakan rumus :

$$
\text { Nilai akhir }=\frac{\text { jumlaHhskor yangdiperolehh }}{\text { skormaksimal }} \times 100
$$

Skor angket mengenai dampak penerapan google classroom terhadap guru dan siswa yang diperoleh selanjutnya dikualifikasikan dengan ketentuan sebagaimana tertera pada tabel berikut :

Tabel. 3 Kualifikasi Hasil Skor Angket Dampak Penerapan Google Classroom Semasa Pandemi Terhadap Guru dan Siswa

\begin{tabular}{cc}
\hline Skor Angket & Kategori \\
\hline $80,00 \leq$ Skor $\leq 100$ & Sangat Baik \\
\hline $66,00 \leq$ Skor $\leq 79,99$ & Baik \\
\hline $56,00 \leq$ Skor $\leq 65,99$ & Cukup \\
\hline $40,00 \leq$ Skor $\leq 55,99$ & Kurang \\
\hline $0 \leq$ Skor $\leq 19,99$ & Sangat Kurang \\
\hline
\end{tabular}


Keabsahan Data dilakukan untuk membuktikan apakah penelitian yang dilakukan benarbenar merupakan penelitian ilmiah sekaligus untuk menguji data yang dipereleh. Uji keabsahan data pada penelitian kualitatif dengan menggunakan triangulasi akan lebih meningkatkan kekuatan data apabila dibandingkan dengan satu pendekatan. Dalam penelitian ini, peneliti menggunakan teknik keabsahan data dengan triangulasi teknik. Triangulasi teknik yaitu peneliti menggunakan teknik pengumpulan data yang berbeda-beda untuk mendapatkan data dari sumber yang sama.

Teknik analisis data yang digunakan dalam penelitian ini adalah teknik analisis data kualitatif dengan menggunakan model Miles dan Hubberman (dalam Sugiyono, 2017:337), model tersebut meliputi tiga komponen yaitu: 1. Data reduction (reduksi data), 2. Data display (penyajian data), 3. Counclucion drawing (penarikan kesimpulan).

\section{HASIL DAN PEMBAHASAN}

Berdasarkan hasil skor angket penelitian dari 2 guru mengenai dampak penerapan google classroom semasa pandemi terhadap guru di SMK Negeri 1 Marancar dapat dilihat pada tabel di bawah ini.

Tabel.4 Hasil Skor Angket Dampak Penerapan Google Classroom Semasa Pandemi Terhadap Siswa Di SMK Negeri 1 Marancar

\begin{tabular}{cccc}
\hline No & Nama Guru & Skor & Kategori \\
\hline 1 & SRH & 67 & Baik \\
\hline 2 & HHL & 66 & Baik \\
\hline & Total & $\frac{\mathbf{1 3 3}}{\mathbf{2}}=\mathbf{6 6 , 5}$ & Baik \\
\hline
\end{tabular}

Berdasarkan hasil angket yang telah diberikan kepada guru matematika maka dapat disimpulkan bahwa terdapat dampak positif dan dampak negatif yang terjadi selama penerapan google classroomdalam pembelajaran daring semasa pandemi. Adapun salah satu dampak yang menyeluruh terjadi kepada guru yaitu guru lebih mengetahui penggunaan ICT yang dapat membantu guru dalam melaksanakan proses pembelajaran daring dengan menggunakan google classroomdengan lebih baik lagi dan sulitnya guru dalam menerapkan metode serta model pembelajaran yang tepat untuk digunakan selama proses pembelajaran daring dengan menggunakan google classroom. Berdasarkan hasil skor angketpenelitian dari 10 siswa mengenai angketdampak penerapan google classroom semasa pandemi terhadap siswa di SMK Negeri 1 Marancar dapat dilihat pada tabel di bawah ini.

Tabel 4.2

Hasil Skor Angket Dampak Penerapan Google Classroom Semasa Pandemi Terhadap Siswa Di SMK Negeri 1 Marancar

\begin{tabular}{cccc}
\hline No & Nama Siswa & Skor & Kategori \\
\hline 1 & AR & 72 & Baik \\
\hline 2 & AS & 81 & Sangat Baik \\
\hline 3 & IA & 85 & Sangat Baik \\
\hline 4 & IM & 72 & Baik \\
\hline 5 & MH & 82 & Sangat Baik \\
\hline 6 & MA & 78 & Baik \\
\hline 7 & NP & 79 & Baik \\
\hline 8 & NS & 72 & Baik \\
\hline 9 & TA & 72 & Baik \\
\hline 10 & WS & $\mathbf{7 5}$ & Baik \\
\hline & Total & $\mathbf{7 7 2}=\mathbf{7 7 , 2}$ & Baik
\end{tabular}

Hasil penelitian yang diperoleh menunjukkan bahwa terdapat dampak penerapan google classroom semasa pandemi terhadap guru dan dampak penerapan google classroom semasa pandemi terhadap siswa di SMK Negeri 1 Marancar. Berdasarkan hasil penelitian yang dilakukan peneliti berdasarkan angket dan wawancara yang diberikan kepada guru dan siswa maka dapat diketahuai dampak penerapan google classroom semasa pandemi terhadap guru dan dampak 
penerapan google classroom semasa pandemi terhadap siswa punya sisi positif dan negatif yang disajikan sebagai berikut :

Dampak penerapan google classroom semasa pandemi terhadap guru

1. Guru lebih mengetahui tentang penggunaan ICT (information communication tecnology) dengan menggunakan google classroom.

2. Waktu mengajar yang digunakan lebih singkat dengan menggunakan google classroom.

3. Proses pembelajaran dapat dilakukan dimana pun dan kapan pun ketika ada waktu luang dan ketika terhubung dengan internet.

4. Menggunakan media pembelajaran seperti smartphone, tablet dan laptop.

5. Sulitnya penerapan metode pembelajaran yang dilakukan dengan menggunakan google classroom.

6. Proses pembelajaran tidak berjalan dengan efektif dan efisien selama pembelajaran menggunakan google classroom.

7. Materi pembelajaran hanya berupa dokumen yang dikirim guru melalui google classroom.

8. Biaya tambahan yang dikeluarkan untuk membeli paket internet saat melaksanakan proses saat pembelajaran menggunakan google classroom.

9. Kerusakan jaringan yang menyebabkan proses pembelajaran terhenti saat pembelajaran menggunakan google classroom.

10. Guru kesulitan dalam membuat media pembelajaran dengan google classroom.

11. Suasana kelas yang kurang menyenangkan selama proses pembelajaran dengan menggunakan google classroom.

12. Meminimalisir penggunaan kertas selama proses pembelajaran dengan menggunakan google classroom.

Dampak Penerapan Google Classroom Semasa Pandemi Terhadap siswa

1. Siswa lebih mengetahui tentang penggunaan ICT (information communication tecnology) dengan menggunakan google classroom.

2. Waktu belajar yang digunakan lebih singkat dengan menggunakan google classroom.

3. Siswa sulit memahami materi yang dikirim guru melalui google classroom yang berupa dokumen.

4. Proses pembelajaran dapat dilakukan dimana pun dan kapan pun ketika ada waktu luang dan ketika terhubung dengan internet.

5. Membutuhkan media pembelajaran seperti smartphone, tablet dan laptop bagi siswa yang tidak memilikinya maka mereka tidak dapat mengikuti poses pembelajaran.

6. Proses pembelajaran tidak berjalan dengan efektif dan efisien selama pembelajaran menggunakan google classroom.

7. Mempermudah siswa dalam mengirimkan tugas selama proses pembelajaran dengan menggunakan google classroom.

8. Membuat rendahnya sopan santun siswa selama menggunakan aplikasi google classroom.

9. Selama proses pembelajaran daring membuat siswa menjadi malam dalam belajar karena siswa tidak memahami materi yang diberikan guru melalui google classroom.

10. Tersedianya tempat penyimpanan file yang memadai.

Hal-hal yang telahdibeutkan ini sejalan dengan hasil penelitian Simanjuntak, dkk (2020) menyatakan bahwa dalam pembelajaran daring ada beberapa kesulitan siswa dan guru yang dialami disamping beberapa dampak positif yang terasa.

\section{KESIMPULAN}

\section{Kesimpulan}

Berdasarkan hasil analisis data yang telah dijabarkan sebelumnya juga dapat ditarik kesimpulan bahwa dengan dilakukannya pembelajaran secara daring dengan penerapan google classroommembuat proses pembelajaran kurang berjalan dengan baik, guru mengalami kesulitan untuk menggunakan metode pembelajaran, siswa sulit memahami materi yang diberikan guru serta fasilitas yang disediakan pihak sekolah kurang memadai.

\section{Saran}


Berdasarkan pembahasan dan kesimpulam hasil penelitian, maka penulis memberikan beberapa saran yang dapat dijadikan sebagai masukan yang bermanfaat bagi pihak-pihak terkait berikut ini :

1. Bagi guru agar lebih dapatmemperhatikan siswa yang mengalami kesulitan belajar selama proses pembelajaran daring dengan menggunakan google classroom serta menggunakan metode pembelajaran yang menarik dan menyenangkan selama proses pembelajaran daring dengan menggunakan google classroom. Sehingga guru tidak hanya mengirimkan tugas pentuk pdf saja. Serta guru diharapakan lebih terampil dan kreatif dengan memanfaatkan teknologi yang sudah berkembang pesat saat ini.

2. Bagi orang tua perlu memantau belajar anak selama proses pembelajaran daring dengan menggunakan google classroom. Serta memberikan teguran pada anak jika anak malas melaksanakan proses pembelajaran secara daring dengan menggunakan google classroom, agar anak selalu mengikuti proses pembelajaran dengan baik serta agar anak tidak menyalahgunakan smartphone untuk eksis dimedia sosial melainkan agar anak lebih aktif dalam belajar.

3. Bagi siswa hendaknya memiliki persiapan dalam melaksanakan proses pembelajaran daring dengan menggunakan google classroom. Jika memang tidak memiliki smartphone dan tidak memahai materi yang diberikan guru sebaiknya belajar bersama dengan teman memiliki smartphone dan teman yang lebih mengrti dari kita. Serta siswa diharapkan memilikiminat belajar yang tinggi meski proses pembelajaran dilaksanakan secara daring dengan menggunakan google classroom serta siswa diharapkan lebih aktif dalam belajar. Agar proses pembelajaran dapat berjalan dengan baik.

\section{REFERENSI}

Elfauziah, Ula Nisa, Suryani, Lilis dan Syahrizal, Trisnendri (2019). Penerapan google classroom dalam pembelajaran bahasa inggris pada guru-guru bahasa inggris SMP di jawa. Jurnal pengambdian kepada masyarakat (Abdinasmas) Vol, 2, No. 2:184-186.

Firman dan Sri Rahayu Rahman (2020). Pembelajaran Online Di Tengah Pandemi Covid-19. Indonesian Jurnal Of Education Science (IJES), vol. 02, No. 02: 81-82.

Harahap, Muhammad Syahril Dan Fauzi Rahmad. (2017). Pengembangan Modul Pembelajaran Matematika Berbasis Web. Jurnal Education. Vol. 4, No. 5:14.

Harianja, Sri Rohana, (2021), wawancara pada tanggal 05 Maret 2021.

Nirfayanti dan Nurbaeti.(2019). Pengaruh Media Pembelajaran Google Classrom Dalam Pembelajaran Analisis Real Terhadap Motivasi Belajar Mahasiswa. Penelitian Matematika Dan Pendidikan.Vol.1. No. 2:51-59.

Rambe, Nelli. 2020. Peningkatan Kemampuan Penalaran Matematis Siswa Melalui Penggunaan Model Problem Posing di SMP Swasta Tapian Nauli. Skripsi, Program Studi Pendidikan Matematika, Institut Pendidikan Tapanuli Selatan.

Shahinaz dan Abdelrahman, O, B. (2017). The Impact Of Google Classroom Application On The Teaching Efficiency Of Pre-Teachers. International jurnal Social Sciences And Education 7:45-54.

Silalahi, Urben. (2012). Metode penelitian sosial. Bandung: Refika Aditama.

Simanjuntak, D. R., Ritonga, M. N., \& Harahap, M. S. (2020). ANALISIS KESULITAN BELAJAR SISWA MELAKSANAKAN PEMBELAJARAN SECARA DARING SELAMA MASA PANDEMI COVID-19 Oleh. Mathematic Education Journal)MathEdu, 3(3), 142146. http://journal.ipts.ac.id/index.php/

Sugiyono. (2011). Metode penelitian kombinasi (Mixed Methods). Bandung:Alfabeta.

Tarihoran, Vinni Altenita.Siregar, Eva Yanti Siregar dan Harahap, Sinar Depi. (2020). Efektivitas model pembelajaran group investigasi (GI) dalam meningkatkan kemampuan komunikasi matematis siswa di kelas VIII SMP Negeri 5 Padangsidimpuan. Jurnal MathEdu (Mathematic Education Journal). Vol. 3, No. 2:75-81.

W, Gulo. Metodologi penelitian. Jakarta : Gramedia.

Yo, Ceng Giap, Riki, Sonny Santoso, Rini Novianti, dkk. (2020). Pembelajaran E-learning dimasa pandemi covid-19. Yogyakarta: Budi utama. 
ISSN. 2621-9832

JURNAL MathEdu (Mathematic Education Journal)

http://journal.ipts.ac.id/index.php/MathEdu Vol. 4 No. 2 Juli 2021

Yuswanti. (2015). Penggunaan media gambar untuk meningkatkan hasil belajar siwa pada pembelajaran IPS di kelas IV SD PT. Lestari Tani Teladan (LTT) KabupatenDonggala. Jurnal kreatif tadulako online. Vol .3, No. 4:185-193. 